Corrigendum

\title{
Corrigendum to "Oleuropein-Induced Apoptosis Is Mediated by Mitochondrial Glyoxalase 2 in NSCLC A549 Cells: A Mechanistic Inside and a Possible Novel Nonenzymatic Role for an Ancient Enzyme"
}

\author{
Cinzia Antognelli $\mathbb{C}^{1},{ }^{1}$ Roberta Frosini, ${ }^{1}$ Maria F. Santolla $\mathbb{D}^{1},{ }^{2}$ Matthew J. Peirce ${ }^{\mathbb{D}},{ }^{1}$ \\ and Vincenzo N. Talesa ${ }^{1}$ \\ ${ }^{1}$ Department of Experimental Medicine, University of Perugia, Perugia 06129, Italy \\ ${ }^{2}$ Department of Pharmacy, Health and Nutritional Sciences, University of Calabria, 87036 Rende, Italy \\ Correspondence should be addressed to Cinzia Antognelli; cinzia.antognelli@unipg.it
}

Received 24 August 2020; Accepted 24 August 2020; Published 11 September 2020

Copyright (c) 2020 Cinzia Antognelli et al. This is an open access article distributed under the Creative Commons Attribution License, which permits unrestricted use, distribution, and reproduction in any medium, provided the original work is properly cited.

In the article titled "Oleuropein-Induced Apoptosis Is Mediated by Mitochondrial Glyoxalase 2 in NSCLC A549 Cells: A Mechanistic Inside and a Possible Novel Nonenzymatic Role for an Ancient Enzyme" [1], there were apparent discontinuities in the western blots in Figures 2 and 4, as raised in PubPeer [2]. The authors provided an explanation, the original files used to prepare the figures, and independent replicates, which are available in Supplementary Materials.

\section{Supplementary Materials}

The authors provided a "letter of clarification," the original files for Figures 2 and 4, and independent replicates. (Supplementary Materials)

\section{References}

[1] C. Antognelli, R. Frosini, M. F. Santolla, M. J. Peirce, and V. N. Talesa, "Oleuropein-induced apoptosis is mediated by mitochondrial glyoxalase 2 in NSCLC A549 cells: a mechanistic inside and a possible novel nonenzymatic role for an ancient enzyme," Oxidative Medicine and Cellular Longevity, vol. 2019, Article ID 8576961, 10 pages, 2019.

[2] "Oleuropein-induced apoptosis is mediated by mitochondrial glyoxalase 2 in NSCLC A549 cells: a mechanistic inside and a possible novel nonenzymatic role for an ancient enzymePubPeerSeptember 15, 2019 https://pubpeer.com/publications/ 3FC40B5E066FEB5212E5B4E0DAD305. 